\title{
PENGARUH JUMLAH ALIRAN UDARA TERHADAP NYALA API EFEKTIF DARI REAKTOR GASIFIKASI BIOMASSA TIPE FIXED BED DOWNDRAFT MENGGUNAKAN BAHAN BAKAR TONGKOL JAGUNG
}

\author{
Romi Djafar ${ }^{1)}$, Farid Darise ${ }^{2)}$ \\ ${ }^{1,2}$ Program Studi Mesin dan Peralatan Pertanian, Politeknik Gorontalo \\ Email : romidjafar@poligon.ac.id ${ }^{1)}$
}

\begin{abstract}
ABSTRAK
Salah satu parameter penting dalam proses gasifikasi adalah perbandingan udara aktual terhadap jumlah bahan bakar disebut udara Air Fuel Rasio (AFR). Ketika AFR terlalu besar maka semakin memperkaya komposisi $\mathrm{CO}_{2}$ dan $\mathrm{H}_{2} \mathrm{O}$ karena pembakaran semakin mendekati pembakaran sempurna. Sedangkan apabila AFR terlalu kecil maka produk arang yang dihasilkan makin meningkat, jumlah produksi gas yang menjadi sedikit dan panas kalor dihasilkan juga makin rendah, hal ini dipengaruhi oleh jumlah udara yang disuplai yang minimum. Oleh karena itu, perlu dilakukan penelitian lebih lanjut bagaimana pengaruh suplai udara terhadap proses gasifikasi tersebut.

Penelitian ini bertujuan untuk mengetahui nyala api terbaik, nyala api efektif proses gasifikasi, jumlah komsumsi bahan bakar serta distribusi suhu sepanjang reaktor downdraft. Untuk mendapatkan hasil penelitian maka dilakukan tiga variasi kecepatan udara masing-masing $15 \mathrm{~m} / \mathrm{s} ; 10 \mathrm{~m} / \mathrm{s}$ dan $5 \mathrm{~m} / \mathrm{s}$ menggunakan alat ukur anomometer digital melalui pengaturan bukaan katup yang terpasang pada pipa nozzle.

Hasil penelitian menunjukkan bahwa nyala api terbaik diperoleh pada AFR 1.8 dengan Eqivalen Rasio (ER) 0,25 yang didapatkan pada kecepatan udara $10 \mathrm{~m} / \mathrm{s}$, dengan indikator nyala api yang kebiruan. Sedangkan laju komsumsi bahan bakar tertinggi diperoleh sebesar $1.7 \mathrm{~kg} / \mathrm{jam}$ yang menghasilkan lama nyala api efektif 218 menit.
\end{abstract}

\section{Kata Kunci: Reaktor, Biomassa, AFR, Nyala Api}

\section{ABSTRACT}

One of the important parameters in the gasification process is the right air for fuel called Air Air Fuel Ratio (AFR). If the AFR is too large, it further enriches the composition of CO2 and H2O because combustion is getting nearer perfect. While the AFR is very small, the product increases, the amount of gas produced becomes less and the heat produced is also getting lower, this is done by the minimum amount of air supplied. Therefore, further research is needed on these components.

This study aims to find out what is done, effective process, measurement of fuel and downdraft distribution. To get the results of the study, several air variations can be carried out each $15 \mathrm{~m} / \mathrm{s} ; 10 \mathrm{~m} / \mathrm{s}$ and $5 \mathrm{~m} / \mathrm{s}$ uses a digital anemometer measuring device through setting openings installed on the nozzle pipe.

The results showed that AFR 1.8 was obtained with Equivalent Ratio (ER) 0.25 obtained at an air velocity of $10 \mathrm{~m} / \mathrm{s}$, with a bluish flame indicator. While the highest fuel consumption flow was obtained 1.7 $\mathrm{kg} / \mathrm{hour}$ which resulted in an effective flame duration of 218 minutes.

Keywords: Reactor, Biomass, AFR, Flame

\section{PENDAHULUAN}

\subsection{Latar Belakang}

Krisis energi yang berkelanjutan hingga saat ini, telah berdampak pada beberapa aspek misalnya semakin menipisnya ketersediaan bahan bakar fosil sehingga telah berdampak pada kenaikan harga bahan bakar. Oleh karena itu, untuk meminimalisir masalah keterbatasan cadangan energi yang tidak dapat perbaharui tersebut diperlukan usaha yang terarah dan terprogram untuk mencari energi alternatif. Salah satunya adalah mengembangkan teknologi gasifikasi biomassa untuk mengkonversi limbah pertanian menjadi energi berguna, ramah lingkungan dan sifatnya dapat diperbaharui.
Pengembangan teknologi gasifikasi telah dilakukan melalui berbagai aplikasi dan penelitian yaitu kajian performa integrasi sistem gasifikasi biomassa dengan industri baja yang efisien (Duleeka, dkk., 2015). Tujuan penelitian adalah untuk mendapatkan keseimbangan energi dengan material produksi pada bagian furnance baja yang berbahan bakar LPG yang akan diganti dengan syngas. Penelitian terhadap reaktor gasifikasi downdraft dengan konstruksi sederhana, kadar karbon yang tinggi, dan memiliki kadar abu yang rendah (Reed dan Das, 1998). Namun permasalahan terjadi yaitu partikel tar yang yang dihasilkan masih tinggi. Berdasarkan penelitiannya direkomendasikan bahwa perlu pengaturan parameter operasi reaktor agar diperoleh hasil gasifikasi yang optimal. Lebih 
lanjut review sistem gasifikasi biomassa tipe fixed downdraft dengan syngas untuk aplikasi bahan bakar mesin pembakaran dalam (internal combustion engine (ICE). Hasil analisisnya menyimpulkan bahwa syn-gas dari proses gasifikasi menunjukkan nilai yang sangat baik. Dimana densitasnya yang rendah dilakukan dengan pengurangan kandungan tar melalui dua zona masukan udara serta cleaning system. Namun masalah yang sering terjadi yaitu tidak lancarnya masukan bahan bakar kedalam reaktor gasifikasi yang menyebabkan meningkatnya produksi tar.

Penelitian lainnya yaitu pengaruh suhu reaktor dan ukuran partikel terhadap karakterisasi gasifikasi biomassa tongkol jagung pada reactor downdraft (Chopra dan Jain, 2007). Penelitian dilakukan secara eksperimental untuk mengetahui kualitas dan kuantitas syn-gas yang dihasilkan dari reaktor gasifikasi downdraft dengan bahan bakar tongkol jagung. Dari hasil eksperimen disimpulkan bahwa produksi syn-gas pada proses gasifikasi dipengaruhi secara signifikan oleh suhu reaktor dan ukuran partikel biomassa. Suhu reaktor yang tinggi dan ukuran partikel biomassa yang kecil (Sudarmanta dan Kadarisman, 2010).

Selanjutnya kajian eksperimen terhadap gasifier biomassa tipe downdraft dari limbah kayu (Sheth dan Babu, 2009). Tujuan penelitian yaitu menentukan kondisi operasi downdraft biomassa berupa limbah kayu yang akan dibandingkan penelitian sebelumnya. Evaluasi kinerja gasifier melalui pengaturan parameter-parameter berupa Equivalence Ratio (ER), komposisi produser gas, nilai kalori rendah dari produser gas. zona laju produksi gas, zona temperatur dan efisiensi gas dingin yang dihasilkan. Hasil penelitian menyimpulkan perbandingan reaktor yaitu reaktor updraft sangat baik untuk bahan bakar dengan kandungan kadar air yang tinggi. Sedangkan reaktor downdraft hanya cocok maksimal kandungan moisture tidak lebih dari $40 \%$ basis kering. Pengaruh parameter operasi dan kualitas gas dari gasifier biomassa tipe downdraft dengan dua masukkan suplai udara (Galindo, dkk., 2014). Tujuan penelitian adalah menentukan pengaruh berbagai regimes operasi dari gasifier dua tingkatan masukan udara, kandungan partikel tar dari produser gas, untuk menentukan titik operasi optimum yang dibutuhkan untuk menghasilkan kriteria yang berkualitas. Metode penelitian dilakukan dengan cara memvariasikan kondisi operasi gasifier berupa aliran udara yaitu dua tingkatan rasio aliran udara. Penelitian lainnya yaitu kajian dan eksperimen pengaruh desain serta parameter kondisi operasi dari proses gasifikasi biomassa tipe downdraft fixed bed (Feiqiang, dkk., 2014). Tujuan penelitian adalah mengetahui pengaruh desain dan kondisi operasi berupa geometri reaktor, ekivalen rasio, laju pemasukkan bahan bakar terhadap performa reaktor downdraft dengan tiga tingkatan masukan udara tipe fixed bed. Sebagai kesimpulan penelitian bahwa untuk meningkatkan laju pemasukkan bahan bakar maka terjadi peningkatan temperatur dalam reaktor. Namun hal ini tidak terlalu memberi konstribusi yang signifikan karena terjadi pembentukan reaksi cracking pada saat proses gasifikasi yang dapat mengurangi kadar $\mathrm{H} 2$ dan $\mathrm{CO}$ serta menghasilkan kandungan tar yang tinggi.

Beranjak dari beberapa referensi sebelumnya maka pada penelitian ini bertujuan untuk mengetahui nyala api terbaik, nyala api efektif dari proses gasifikasi, jumlah komsumsi bahan bakar dan distribusi suhu sepanjang reaktor selama proses pengujian. Pengujian dilakukan melalui pengaturan parameter operasi berupa perbandingan udara dan bahan bakar atau memvariasikan Air Fuel Rasio (AFR) aktual masing-masing 1,6; 1,8; dan 1,1 menggunakan bahan bakar tongkol jagung.

\section{METODE PENELITIAN}

\subsection{Landasan Teori}

Gasifikasi adalah proses kimia yang mengubah material karbon seperti biomassa menjadi bahan bakar gas yang mudah digunakan baik dalam skala rumah tangga, industri dan penggunaan lainnya. Dalam proses gasifikasi dapat terjadi karena adanya pemberian udara dalam jumlah yang terbatas untuk menghasilkan gas mampu bakar seperti CO, H2, CH4. Selanjutnya produk lainnya yang diperoleh dari proses gasifikasi yaitu kadar abu dan partikel tar.

Proses gasifikasi pada prinsipnya memiliki 4 tahapan yaitu proses pengeringan, pyrolisis, oksidasi parsial dan proses reduksi yang semuanya terjadi secara alamiah pada saat proses pembakaran.

a. Proses Pengeringan (drying)

Akibat pengaruh panas biomassa mengalami pengeringan yang terjadi pada kisaran suhu sebesar $100-200^{\circ} \mathrm{C}$. Proses ini merupakan pelepasan kandungan air dalam bentuk uap air. Namun tidak terjadi dekomposisi kimia pada biomassa.

b. Proses pirolisis terjadi pada suhu interval suhu $250-500^{\circ} \mathrm{C}$. Akibat suhu yang sangat tinggi maka terjadi perekahan melekul-melekul besar dari biomassa menjadi melekul kecil. Hasil proses pyrolisis yaitu arang (karbon), uap air $\left(\mathrm{H}_{2} \mathrm{O}\right)$, uap tar dan gas-gas lainnya. Selanjutnya arang tersebut akan mengalami oksidasi parsial.

c. Proses oksidasi parsial merupakan tahapan yang sangat penting dalam proses gasifikasi yaitu biomassa hasil pirolisis dibakar dengan udara untuk menghasilkan panas yang dibutuhkan proses-proses lainnya. Proses oksidasi berlangsung diatas suhu $900^{\circ} \mathrm{C}$ untuk membantu perekehan partikel Tar lebih lanjut.

d. Proses reduksi terjadi pada kisaran suhu diatas $300^{\circ} \mathrm{C}$ yaitu arang bereaksi dengan uap air $\left(\mathrm{H}_{2} \mathrm{O}\right)$ dan karbon dioksida (CO2). Untuk 
menghasilkan hidrogen dan karbon monoksida sebagai komponen utama gas proses gasifikasi.

Analisis yang dilakukan pada penelitian ini difokuskan pada parameter operasi yaitu rasio Ekivalen Rasio (ER). Mendapatkan nilai ER maka terlebih dahulu mengetahui rasio udara dan bahan bakar (AFR) aktual dengan AFR stoikiometri. Nilai AFR aktual didapatkan dari perbandingan massa udara dan massa bahan bakar yang dibutuhkan dapat ditulis dengan persamaan:

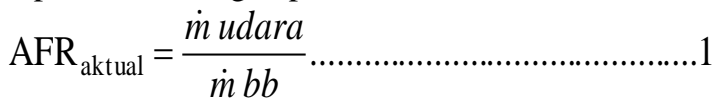

Sedangkan AFR stoikiometri dihitung berdas arkan data analisis proximate dan ultimate bahan bakar tongkol jagung.

Tabel 1. Hasil Proximate dan Ultimate Tongkol Jagung.

\begin{tabular}{|c|l|c|c|}
\hline No & \multicolumn{1}{|c|}{ Parameter } & Unit & Nilai \\
\hline 1 & Moisture Content & $\% \mathrm{wt}$ & 10,15 \\
\hline 2 & Ash Content & $\% \mathrm{wt}$ & 1,80 \\
\hline 3 & Volatile Matter & $\% \mathrm{wt}$ & 87,90 \\
\hline 4 & Fixed Carbon & $\% \mathrm{wt}$ & 0,15 \\
\hline 5 & Density & $\mathrm{Kg} / \mathrm{m} 3$ & 296 \\
\hline 6 & LHV & $\mathrm{MJ} / \mathrm{kg}$ & 10,85 \\
\hline \multirow{3}{*}{7} & \multirow{3}{*}{ Komponen } & $\mathrm{C}$ & 47,60 \\
\cline { 3 - 4 } & & $\mathrm{H}$ & 5,91 \\
\cline { 3 - 4 } & & $\mathrm{N}$ & 0,84 \\
\cline { 3 - 4 } & & $\mathrm{S}$ & 0,15 \\
\cline { 3 - 4 } & & $\mathrm{O}$ & 38,70 \\
\hline
\end{tabular}

Sumber (Sudarmanta dan Kadarisman, 2010)

Berdasarkan data analisis ultimate maka dapat dihitung perbandingan udara dan bahan bakar dinyatakan dalam $\mathrm{kg}$ udara per $\mathrm{kg}$ bahan bakar atau $\mathrm{kg}$ mol udara per kg mol bahan bakar. Pada proses pembakaran sempurna, maka unsur-unsur kimia batubara berupa $\mathrm{C}, \mathrm{H}_{2}$ dan $\mathrm{S}$ bereaksi dengan $\mathrm{O}_{2}$, sedangkan $\mathrm{N}_{2}$ tidak bereaksi dengan $\mathrm{O}_{2}$. Sehingga hasil reaksi kimia stoikiometri sebagai berikut.

Reaksi kimia pembakaran menggunakan cara yang sama pada basis $1 \mathrm{~kg}$ batubara yang digunakan pada pemodelan sebagai berikut.

a. $0,4760 \mathrm{~kg}$ karbon $(\mathrm{C})$ butuh oksigen $\left(\mathrm{O}_{2}\right)$ :

$$
\mathrm{O}_{2} \rightarrow 0,760 \times 32 / 12=1,26
$$

product $\rightarrow 0,4760 \times 44 / 12=1,74$

b. $0,0591 \mathrm{~kg}$ Hidrogen $(\mathrm{H})$ butuh oksigen $\left(\mathrm{O}_{2}\right)$ :

$$
\mathrm{O}_{2} \rightarrow 0,0591 \times 16 / 2=0,472
$$

$$
\text { product } \rightarrow 0,0951 \times 18 / 2=0,53
$$

c. $0,0015 \mathrm{~kg}$ Sulfur $(\mathrm{S})$ memerlukan oksigen $\left(\mathrm{O}_{2}\right)$

$$
\begin{aligned}
& \mathrm{O}_{2} \rightarrow 0,0015 \times 32 / 32=0,0015 \\
& \text { product } \rightarrow 0,0019 \times 64 / 32=0,003
\end{aligned}
$$

Total oksigen $\left(\mathrm{O}_{2}\right.$ total) yang dibutuhkan untuk membakar $1 \mathrm{~kg}$ batubara secara sempurna yaitu 1,26 $+0,472+0,003=1,7 \mathrm{~kg}$
Oleh karena itu, secara teoritis udara yang dibutuhkan oleh pembakaran sempurna sebagai berikut.

$1,7 / 0,233=7.2 \mathrm{~kg} / \mathrm{kg}$ tongkol jagung.

Catatan: nilai 0233 konstanta fraksi massa oksigen dalam udara kering.

Dengan Demikian equivalen rasio dengan dihitung dengan persmaan sebagai berikut.

$$
E R=\frac{\left(\dot{m}_{\text {udara }} / \dot{m}_{b b(a r)}\right) \text { aktual }}{\left(\dot{m}_{\text {udara }} / \dot{m}_{b b(\text { ar })}\right) \text { Stoich }}=\frac{A F R_{\text {aktual }}}{A F R_{\text {Stoich }}} \quad \ldots 2
$$

\begin{tabular}{l|l|l}
$\mathrm{AFR}=1.6$ & $\mathrm{AFR}=1.8$ & $\mathrm{AFR}=1.1$ \\
\hline
\end{tabular}

\subsection{Skema Pengujian}

Penelitian ini dilakukan menggunakan reaktor gasifikasi biomassa tipe downdraft dengan dua laluan udara. Reaktor gasifikasi terbuat dari pelat galvanis steel dengan ketebalan $2 \mathrm{~mm}$. Sedangkan tinggi reaktor sebesar $115 \mathrm{~cm}$ dengan diameter $50 \mathrm{~cm}$. Pada bagian tengah reaktor dibuat penyempitan diameter yaitu throat reaktor dengan ukuran diameter $15 \mathrm{~cm}$ dan tinggi $20 \mathrm{~cm}$. didalam reaktor dipasang Glasswall untuk mereduksi energi panas yang keluar. Selanjutnya di dalam reaktor dipasang sensor suhu yaitu termokopel tipe $\mathrm{K}$ sebanyak 5 titik dipasang sepanjang ketinggian reaktor T1 zona drying, T2, T3, zona pirolisis, T4 zona oksidasi, dan T5 zona eduksi. Skema reaktor gasifikasi ditunjukkan pada Gambar 1 sebagai berikut.

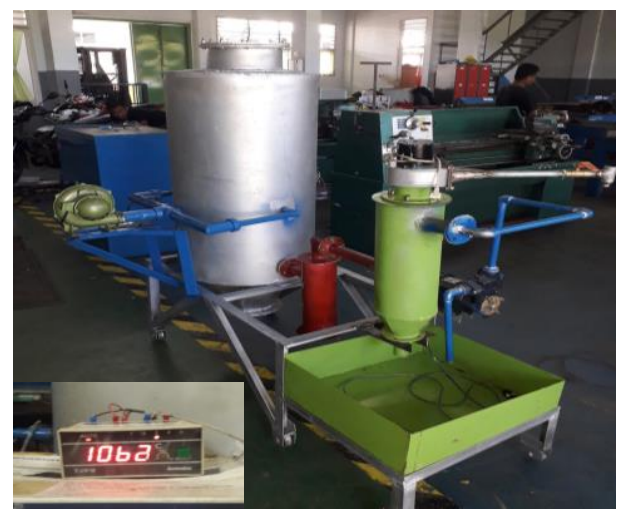

Gambar 1. Reaktor Gasifikasi Tipe Downdraft.

Reaktor gasifikasi biomassa yang terdapat pada Gambar 1 merupakan reaktor tipe downdraft yang dilengkapi dengan kelengkapan gas cleaning berupa cyclone, water scruber, blower dorong, blower sentrifugal dan kontrol suhu (PID Control).

\subsection{Prosedur Eksperimen}

Proses pengujian dapat berlangsung dengan baik dengan memperhatikan beberapa tahapan sebagai berikut:

1. Persiapan biomassa berupa tongkol jagung sebagai bahan bakar berdasarkan pengukuran menggunakan moisture meter sebesar $12 \%$. 
2. Pemerikasaan kondisi reaktor mulai dari kebersihannya, pengecekan bagian kelengkapan reaktor dipastikan dapat berfungsi dengan baik.

3. Masukkan bahan bakar tongkol jagung sampai batas nozzle selanjutnya dilakukan penyalaan awal dibantu dengan kertas yang dicelupkan pada solar untuk mempermudah start-up.

4. Kemudian atur kecepatan udara yang disulai oleh blower dengan mengatur katup yang terpasang dipipa/nozzle diluar reaktor sesuai ukuran bukaan katup dibutuhkan.

5. Apabila api sudah menyala dengan temperatur diatas $500^{\circ} \mathrm{C}$ selanjutnya reaktor di isi full $(5 \mathrm{~kg} /$ batch $)$ kemudian hopper inlet ditutup rapat.

6. Mulai pengambilan data setelah kondisi steadi atau kurang lebih 15 menit proses penyelaan api dilakukan.

7. Rentang waktu pengambilan data setiap 5 menit setelah kondisi steadi yaitu mulai terjadi nyala api gas mampu bakar sampai dengan nyala api akan padam tersebut.

\section{HASIL DAN PEMBAHASAN}

Pengujian reaktor gasifikasi biomassa menggunakan bahan bakar tongkol yang memiliki kadar air sebesar $12 \%$. Pengujian dilaksanakan sebanyak tiga kali masing-masing jumlah bahan bakar $5 \mathrm{~kg}$ untuk tiap batch pengujian. Berdasarkan pengujian terlebih dahulu menentukan laju suplai udara menggunakan anomometer masing-masing $15 \mathrm{~m} / \mathrm{s} ; 10 \mathrm{~m} / \mathrm{s}$ dan $5 \mathrm{~m} / \mathrm{s}$. Agar didapatkan jumlah volumetrik udara maka kecepatan udara harus dikonversi dengan mengalikan kecepatan udara tersebut dengan luasan area dari pipa yang digunakan. Dengan demikian, nilai massa udara dapat digunakan untuk menghitung Air fuel ratio (AFR) aktual. Sehingga dapat ditentukan Eqivalen Rasio (ER) dari masing-masing pengujian. Adapun variasi kecepatan udara masing-masing pengujian ditunjukkan pada Tabel 1. Sebagai berikut:

Tabel. 2 Variasi Kecepatan Udara

\begin{tabular}{|c|c|c|c|c|}
\hline $\begin{array}{c}\text { No } \\
\text { Uji }\end{array}$ & $\begin{array}{l}\text { Kec. } \\
\text { Udara } \\
(\mathrm{m} / \mathrm{s})\end{array}$ & $\begin{array}{c}\text { Luasan } \\
\text { Area } \\
\text { Pipa (m) }\end{array}$ & $\begin{array}{c}\text { Volume } \\
\text { Udara } \\
(\mathrm{m} 3)\end{array}$ & $\begin{array}{l}\text { Massa } \\
\text { udara } \\
(\mathrm{kg} / \mathrm{jam})\end{array}$ \\
\hline 1 & 15 & 0.15 & 2.3 & 2.76 \\
\hline 2 & 10 & 0.15 & 1.59 & 1.90 \\
\hline 3 & 5 & 0.15 & 0.79 & 0.94 \\
\hline
\end{tabular}

Tabel 2 Menunjukkan variasi kecepatan udara yang digunakan pada proses penelitian. Untuk mendapatkan massa bahan bakar diperoleh dengan mengalikan volume udara dengan massa jenis udara tersebut. Hasil konversi pada Tabel 2 dapat digunakan menghitung perbandingan Air Fuel Ratio (AFR) aktual dengan massa bahan bakar yang digunakan setiap proses penelitian. Tabel 3 menunjukkan hasil analisis AFR aktual sebagai berikut.
Tabel 3. Air Fuel Ratio (AFR) Aktual

\begin{tabular}{|c|c|c|c|}
\hline $\begin{array}{c}\text { No } \\
\text { Uji }\end{array}$ & $\begin{array}{c}\text { Jlh bb } \\
(\mathrm{Kg} / \mathrm{Jam})\end{array}$ & $\begin{array}{c}\text { m udara } \\
(\mathrm{Kg} / \mathrm{Jam})\end{array}$ & $\begin{array}{c}\text { AFR } \\
\text { aktual }\end{array}$ \\
\hline 1 & 1.7 & 2.76 & 1.6 \\
\hline 2 & 1.07 & 1.9 & 1.8 \\
\hline 3 & 0.83 & 0.94 & 1.1 \\
\hline
\end{tabular}

Nilai AFR aktual yang ditunjukkan pada Tabel 3 merupakan perbandingan massa udara terhadap bahan bakar yang digunakan. Adapun bahan bakar yang digunakan setiap pengujian adalah sebanyak $5 \mathrm{Kg}$ dengan proses gasifikasi berlangsung lebih dari 3 jam sehingga rata-rata laju komsumsi bahan bakar bertutur-turut 1,7; 1,07 dan $0,83 \mathrm{Kg} / \mathrm{Jam}$. Berdasarkan tiga variasi AFR aktual maka hasil visualisasi nyala api proses gasifikasi ditunjukkan pada Gambar 3.1 sebagai berikut.

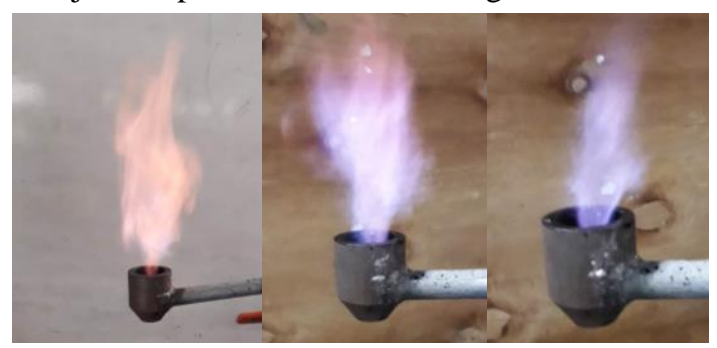

Gambar 3.1 Visualisasi Nyala Api Gasifikasi

Secara teoritis, untuk reaksi gasifikasi, konsep yang biasa dilakukan adalah memberikan fraksi udara stoikiometrik sebesar $1.5 \mathrm{~m}^{3}$, dimana gasifikasi optimum didapatkan pada ER 0.25. Hasil penelitian yang dilakukan sudah sesuai dengan teori tersebut, dimana gasifikasi optimum didapatkan pada kecepatan udara $10 \mathrm{~m} / \mathrm{s}$, dengan volume udara $1.59 \mathrm{~m}^{3}$ dan ER 0.25. Apabila nilai ER meningkat maka terjadi peningkatan suhu akibat peningkatan fraksi $\mathrm{H}_{2}$ sehingga menyebabkan produksi tar menurun. Hal ini sesuai dengan penelitian sebelumya (Feiqiang, dkk., 2014) bahwa dengan meningkatkan nilai ER akan menurunkan jumlah partikel tar. Itulah sebabnya nyala api pada kecepatan udara $15 \mathrm{~m} / \mathrm{s}$ secara visual menjadi berwarna kemerah-merahan akibat kelebihan suplai udara. Pada saat nyala api berwarna kemerahmerahan maka mengindikasikan nyala api tersebut memiliki nilai kalor yang rendah. Hal ini dapat terjadi karena kekurangan udara saat mencampuri proses pembakaran atau campuran kaya. Sedangkan warna api yang kebiruan mengindikasikan nyala api dengan nilai kalor yang tinggi atau campuran miskin.

\subsection{Analisis Ekuivalen Rasio (ER)}

Rasio Ekuivalen (ER) merupakan parameter penting operasi dari gasifier (Raman, dkk., 2013). Nilai ER akan berpengaruh pada kuantitas dan kualitas gas yang dihasilkan. Pada proses gasifikasi diperlukan jumlah udara dalam jumlah yang terbatas. Nilai ER yang terlalu tinggi dan rendah 
akan menimbulkan beberapa persoalan. Jika nilai ER yang terlalu kecil maka mengakibatkan bertambahnya produk char, produksi gas mampu bakar yang kecil serta panas kalor yang rendah. Sebaliknya nilai ER yang tinggi akan meningkatkan gas $\mathrm{CO}_{2}$ dan $\mathrm{H}_{2} \mathrm{O}$ akibat kelebihan suplai udara sehingga proses pembakaran mendekati pembakaran sempurna (Atnawa, dkk., 2013). Berdasarkan hasil analisis Tabel 4. Menunjukkan Ekivalen Rasio sebagai berikut.

Tabel 4. Hasil Analisis Eqivalen Rasio (ER)

\begin{tabular}{|c|c|c|c|}
\hline No & AFR Aktual & AFR Stoich & ER \\
\hline 1 & 1.6 & 7.22 & 0.22 \\
\hline 2 & 1.8 & 7.22 & 0.25 \\
\hline 3 & 1.1 & 7.22 & 0.15 \\
\hline
\end{tabular}

Berdasarkan data hasil analisis pada Tabel 4 diketahui bahwa nilai ER tertinggi pada proses pengujian pertama yaitu 0.25 sedangkan ER terendah sebesar 0.15. Perubahan kenaikan nilai ER sebesar $12.5 \%$ atau kecepatan udara blower $10 \mathrm{~m} / \mathrm{s}$ di dapatkan ER 0.25 dengan visualisasi nyala api terbaik pada penelitian ini. Sedangkan AFR aktual semakin kecil menyebabkan nilai ER juga semakin kecil sehingga dihasilkan produksi syngas semakin sedikit.

\subsection{Distribusi Suhu Proses Gasifikasi}

Selama proses pengujian reaktor maka distribusi suhu diketahui melalui sensor termokopel tipe-K yang representasi suhunya ditunjukkan oleh PID control. Gambar 3.2 menunjukkan distribusi suhu pada proses pengujian sebagai berikut.

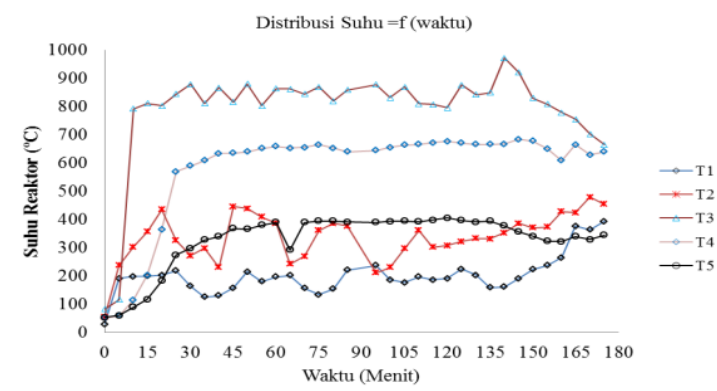

Gambar 3.2 Distribusi Suhu Pada ER 0.22

Grafik pada Gambar 3.2 merupakan distribusi suhu pada ER sebesar 0.25 yang menunjukkan tren line yang berfluktuatif. Pengambilan data pada interval waktu setiap 5 menit dimulai dari kondisi steadi sampai nyala api gas mampu bakar padam. Adapun distribusi suhu sepanjang reaktor untuk masing-masing tahapan proses gasifikasi yaitu terkopel 1 (T1) adalah zona drying dengan inverval suhu $100-200^{\circ} \mathrm{C}$. Pada Zona ini terjadi pelepasan uap air dari bahan bakar. Untuk terkopel 2 (T2) merupakan zona pirolisis dengan batas suhu diatas $300^{\circ} \mathrm{C}$. Sedangkan termokopel 3 (T3) adalah zona oksidasi parsial pada inverval suhu diatas $800-1000^{\circ} \mathrm{C}$ dimana proses ini merupakan tahapan paling penting untuk proses lainnya. Kemudian paling terakhir adalah termokopel 4 (T4) zona reduksi dengan interval suhu $400^{\circ} \mathrm{C}-600^{\circ} \mathrm{C}$. Berdasarkan distribusi suhu dapat disimpulkan bahwa suhu tertinggi yang dapat dicapai adalah $973^{\circ} \mathrm{C}$. Selanjutnya hasil pengujian kedua dapat diketahui dari Gambar 3.3

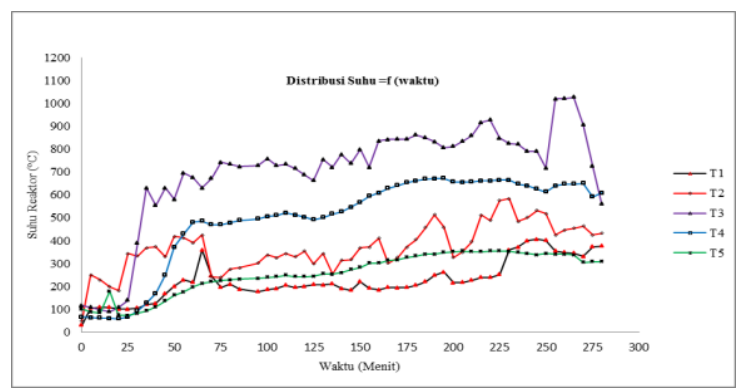

Gambar 3.3 Distribusi Suhu Pada ER 0.25

Hasil distribusi suhu pada Gambar 3.3 merupakan pengujian yang kedua dengan jumlah bahan bakar yang sama yaitu $5 \mathrm{~kg}$. Tren suhu yang dihasilkan pada pengujian ini lebih teratur dibandingkan dengan pengujian pertama. Perubahan distribusi suhu terjadi kenaikan yang signifikan pada termokopel 3 (T3) dengan menit 35 yaitu sebesar $630^{\circ} \mathrm{C}$. Selanjutnya kenaikan suhu secara perlahan mencapai sampai $928^{\circ} \mathrm{C}$ hingga $1021^{\circ} \mathrm{C}$ tertinggi. Pada proses pengujian dapat ditentukan nilai ER yang digunakan yaitu sebesar 0.25 atau dengan air fuel rasio (AFR) aktual 1.8. Hasil visualisasi api yang dihasilkan terdapat kesesuaian perbandingan antara udara dan bakar yang bercampur dengan baik pada proses pembakaran tersebut. Sehingga gas mampu bakar yang dihasilkan lebih berkualitas yang direpresentasikan dengan warna nyala api biruan. Ketika nyala api berwarna kebiruan maka terjadi pembakaran sempurna yang indikasikan heating value juga bernilai besar.

Kemudian pengujian yang terakhir adalah dengan AFR aktual $1.1 \mathrm{~kg} / \mathrm{kg}$ tongkol jagung. Distribusi suhu dari pengujian dapat ditunjukkan pada Gambar 3.4 sebagai berikut.

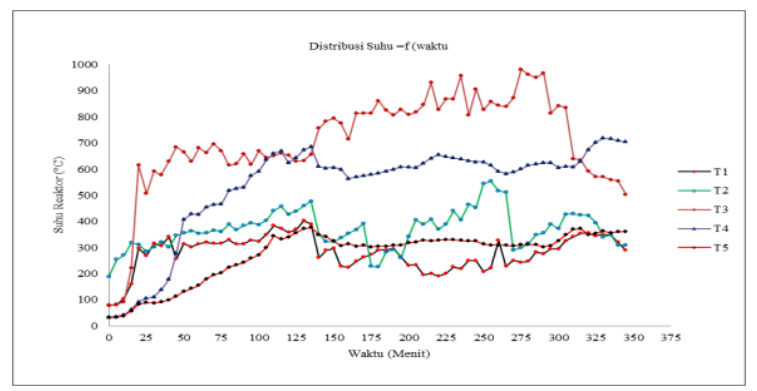

Gambar 3.4 Distribusi Suhu Pada ER 0.15

Berdasarkan tren grafik pada Gambar 3.4 mengindikasikan distribusi suhu yang kembali 
berfluktif signifikan untuk seluruh zona tahapan proses gasifikasi. Sesuai prinsip pembakaran maka hal ini dapat dikatakan terjadi campuran kaya yaitu suplai udara yang di injeksikan keruang bakar dalam kondisi minimum. Akibatnya proses start up membutuhkan waktu yang lama. Hal ini dapat diketahui dari hubungan nyala api terhadap lamanya proses gasifikasi dalam Tabel 5 sebagai berikut.

\begin{tabular}{|c|c|c|c|c|}
\multicolumn{5}{c|}{ Tabel 5 Perbandingan ER terhadap Nyala Efektif. } \\
\begin{tabular}{|c|c|c|} 
No \\
Uji
\end{tabular} & $\begin{array}{c}\text { AFR } \\
\text { aktual }\end{array}$ & $\begin{array}{c}\text { Waktu } \\
\text { nyala } \\
\text { Api }\end{array}$ & $\begin{array}{c}\text { Nyala } \\
\text { Api } \\
\text { Padam }\end{array}$ & $\begin{array}{c}\text { Nyala Api } \\
\text { Efektif }\end{array}$ \\
\hline 1 & 1.6 & $18 "$ & $235^{\prime \prime}$ & 218 Menit \\
\hline 2 & 1.8 & $42^{\prime \prime}$ & $245^{\prime \prime}$ & 204 Menit \\
\hline 3 & 1.1 & $55^{\prime \prime}$ & $255^{\prime \prime}$ & 205 Menit \\
\hline
\end{tabular}

Hasil pengujian yang ditunjukkan pada Tabel 5 merupakan hubungan AFR aktual terhadap nyala api efektif yang dihasilkan. Pada AFR 1.6 waktu start up terjadi dalam waktu yang singkat yaitu pada menit 18 sudah terjadi nyala api gasifikasi dan padam padam menit 235 sehingga nyala api efektif diperoleh 218 menit. Namun jika dilihat dari kuantitas dan kualitas dari gas mampu bakar yang dihasilkan, mengindikasikan nilai kalor panas yang rendah (Gambar 3.1). Sebaliknya ketika AFR ditingkatkan menjadi 1.8 atau naik sebesar $12 \%$ maka pengaruhnya terhadap star-up menjadi relatif lama yaitu menit 42 terjadi nyala api dan dihasilkan nyala efektif 204 menit untuk $5 \mathrm{~kg}$ bahan bakar. Sementara AFR 1.1 Perubahan lama start-up, nyala api padam dan nyala api efektif tidak terlalu jauh dari pengujian kedua. Berdasarkan visualisasi nyala api (Gambar 3.1 ) terlihat warna api lebih bersih, namun dalam jumlah yang lebih kecil. Untuk mengetahui durasi waktu gasifikasi berdasarkan jumlah bahan bakar terdapat pada Tabel 6 sebagai berikut.

Tabel 6 Jumlah Bahan Bakar Terhadap Lama Waktu Gasifikasi.

\begin{tabular}{|c|c|c|c|}
\hline No Uji & $\begin{array}{c}\text { AFR } \\
\text { Aktual }\end{array}$ & $\begin{array}{c}\text { Bahan } \\
\text { Bakar }\end{array}$ & $\begin{array}{c}\text { Waktu } \\
\text { Gasifikasi }\end{array}$ \\
\hline 1 & 1.6 & $5 \mathrm{Kg}$ & 175 Menit \\
\hline 2 & 1.8 & $5 \mathrm{Kg}$ & 280 Menit \\
\hline 3 & 1.1 & $5 \mathrm{Kg}$ & 361 Menit \\
\hline
\end{tabular}

Berdasarkan Tabel 6 menunjukkan lama proses gasifikasi yang variatif. Adapun hasil pengujian dengan AFR 1.6 atau dengan suplai kecepatan udara yang disuplai kedalam reaktor 15 $\mathrm{m} / \mathrm{s}$ terhadap jumlah $5 \mathrm{~kg}$ bahan bakar tongkol jagung diperoleh total lamanya proses gasifikasi adalah 175 menit. Sedangkan pada saat AFR ditingkatkan menjadi 1.8 maka di dapatkan durasi waktu gasifikasi sebesar 280 menit. Selanjutnya jika AFR dalam kondisi minimum maka didapatkan total proses gasifikasi 361 menit.

\section{KESIMPULAN}

Berdasarkan hasil pengujian yang telah dilakukan pada penelitian ini dapat disimpulkan sebagai berikut.

1. Laju aliran udara yang digunakan pada penelitian ini adalah $15 \mathrm{~m} / \mathrm{s} ; 10 \mathrm{~m} / \mathrm{s}$ dan $5 \mathrm{~m} / \mathrm{s}$. dengan hasil perhitungan diperoleh Air Fuel Ratio (AFR) aktual berturut-turut 1,6; 1,8 dan 1,1 .

2. Hasil analisis didapatkan Eqivalen Rasio (ER) dari setiap pengujian adalah 0,$22 ; 0,25$ dan 0,15 .

3. Hasil nyala api terbaik diperoleh pada AFR aktual 1.8 dengan Eqivalen Rasio 0,25 pada kecepatan udara $10 \mathrm{~m} / \mathrm{s}$.

4. Semakin besar suplai udara ke ruang reaktor maka diperoleh nyala api yang kemerahan. Sebaliknya jika kecepatan udara semakin rendah atau jumlah udara dalam kondisi minimum warna api gas mampu bakar makin jernih namun dalam jumlah yang sedikit.

5. Berdasarkan nyala api efektif diperoleh durasi waktu terbaik sebesar 218 menit pada AFR 1.6 dengan laju komsumsi bahan bakar $1.7 \mathrm{~kg} / \mathrm{jam}$

6. Direkomendasikan kedepannya bahwa penelitian ini dapat dilanjutkan dengan analisis dan pengukuran unsur-unsur gas dari proses gasifikasi.

\section{DAFTAR PUSTAKA}

Atnawa, S.M., Sulaiman, S.A, \& Yusup, S. (2013). Syngas production from downdraft gasification of oil palm fronds, Elsevier Energy, 61, 491-501

Chopra, S., \& Jain, A.K. (2007). A Review Of fixed Bed Gasification System for Biomassa. Agricultural Engineering International: the CIGR Ejournal 9(5)

Galindo, A.L., Lora, E.S., Andrade, R.V., Giraldo, S.Y., Jae, R.L., \& Cobas, V.M. (2014). Biomass gasification in a downdraft gasifier with atwo-stage air supply: Effect of operating conditions on gas quality.Biomass and Bioenergy, 6, 236-244.

Gunarathne, D.S, Mellin, P., Yang, W., Pettersson, M., \& Ljunggren, R. (2016). Performance of an effectively integrated biomass multi-stage gasification system and a steel industry heat treatment furnace. Elsevier. Energy, 170, 353-361.

Guo, F., Dong, Y., Dong, L., \& Guo, C. (2014). Effect of design and operating parameters on the gasification process of biomass in a downdraft fixed bed: An experimental study. Elsevier. international journal of hydrogen energy, 39, 5625-5633.

Raman, P., Ram, N.K., \& Gupta, R. (2013). A dual fired downdraft gasifier system to produce cleaner gas for power generation: Design, 
development and performance analysis. India

Reed, T.B., \& Das, A. (1988). Handbook of Biomass Downdraft Gasifier Engine Systems. Golden, CO: Solar Energy Research Institute SERISP-271-3022 DE88001135

Sheth, P.N., \& Babu, B.V. (2009). Experimental studies on producer gas generation from wood waste in downdraft biomassa gasifier. Bioresource Technology, 100, 3127-3133

Sudarmanta, B., \& Kadarisman. (2010). Pengaruh Suhu Reaktor dan Ukuran Partikel Terhadap Karakterisasi Gasifikasi Biomassa Tongkol Jagung Pada Reaktor Downdraft. Seminar Nasional Pascasarjana X - ITS 